\title{
The Impact of XXVII Summer Universiade on the Environment in Kazan
}

Mingazova N.M.

Zamaletdinov R.I.

Derevenskaya O.Yu.

Palagushkina O.V.

Nabeeva E.G.

Pavlova L.R.

Shigapov I.S.

Mingaliev R.R.

Nazarov N.G.

Zaripova N.R.

Kazan Federal University, Institute of Management, Economics and Finance, Kazan, 420008, Russia

Doi:10.5901/mjss.2015.v6n1s3p470

\section{Abstract}

This article introduces general research results of impact of XXVII Summer Universiade on the environment in Kazan. There are major results of ecological consequences of staging of Universiade for development of Kazan city and the Tatarstan Republic. The scientific assessment is given in the integrated form by indicators.

Keywords: International competitions, XXVII Summer Universiade, environmental impact assessment, Kazan city, Tatarstan Republic.

\section{Introduction}

The significancy of international sports competitions should be contemplated in different details. The sports competitions introduce a great contribution to the international collaboration, strengthening peace and mutual understanding between people. The large sports competitions are powerful stimulus for development of social and economic systems of cities and regions (which are venue of competitions), modernization of all aspects of population`s life [2,10]. Competition organizers trying to calculate consequences of staging of them at all spheres of life, with economics, social and cultural sphere and environment previously.

At the present time assessment of the significance of sports events of international scope is also need to view from the position of the conception of sustainable development. According to this conception, today's satisfaction of wants is possible without risk of future generation`s ability to meet their own needs. The main aspect of the conception of sustainable development is state of environment.

The aim of research is assessment of impact of XXVII Summer Universiade on the environment to development of city and republic in ecological sphere by the conception of sustainable development. Universiade was attending from 6 to 17 July 2013 in Kazan.

\section{Materials and Methods}

The present work was carried out under the program contract between Kazan (Volga region) Federal University and the Executive directorate of the XXVII World Summer Universiade 2013 in Kazan.

Research made in 2012-2014 year on a number of indicators: 1) water quality and assessment of the ecological 
status of water objects; 2) air quality, and the emission of gases which cause the greenhouse effect; 3) sewage treatment; 4) the new treatment plant and waste water treatment plants; 5) taking into account the area of green space, the extent of landscaping and assessment of green spaces of the city; 6) assessment of Protected Areas; 7) biodiversity and valuable natural areas. Research of environmental impact assessment included study of the effect on the state of the city and the region.

The methods were developed for assessing the dynamics of each indicator [6,7]. The initial state of the component of the environment, relating to 2009, estimates the value of $1(100 \%)$ for each indicator. Dynamics of changes was evaluated in accordance with the proportions change indicator values in fractions of $1[6]$.

The materials for research are own results of investigations and measurements in 2009-2014 year, fund materials organizations, statistical materials, the results of the poll.

\section{Results and Discussion}

1. Water quality and assessment of the ecological state of water objects. The organization of the Universiade 2013 in Kazan had an impact on water objects due to the construction of sports facilities in the coastal areas, as well as the construction of infrastructure.

For the Kuibyshev reservoir and river Kama direct impact on the construction of the Universiade is not observed characteristic recreational impact, there is recreational impact.

Preparation and staging of the Universiade had some influence on the ecological state of water objects of Kazan city. Rowing Sports Center was built on Lake Middle Kaban, and water area of the lake was used for rowing. Some values of Universiade were built on artificial bulk ground of Kazanka river (football stadium Kazan-Arena, Palace of water sports, Center of beach volleyball [10].

Impacts on water objects in the process of preparation and staging of the Universiade was ambiguous from view of the assessment of the state of water objects. During the building of values (2010-2012 year) effects were mostly negative, especially on the river Kazanka. During the construction of sports facilities were covered with sand about 60 hectares (near 150 acres) of floodplain meadows and shallow areas, which previously were occupied by aquatic vegetation. This complex of macrophytes, bacteria and algae performs an important function of the natural bio filter contribute to the natural self-purification of the river. These were phytophilic spawning fish species, as well as rare species of plants. Water objects received a lot of suspended solids and oil from construction equipment and transport. By the results of the analysis and measurement, consequences of the construction caused the deterioration of water quality and ecological state of water objects [3].

The negative impact of the construction of Universiade objects on the banks of two water bodies (Kazanka river downstream and Lake Middle Kaban) led to a decrease in the indicator data (2009-2014) from 1 to 0.8 (table 1).

Table 1. The integral assessment of dynamics of environment indicators

\begin{tabular}{|c|c|c|c|c|c|}
\hline \multirow{2}{*}{ Indicator } & \multicolumn{5}{|c|}{ Year } \\
\hline & 2009 & 2010 & 2011 & 2012 & 2013 \\
\hline Water quality and assessment of the ecological state of water bodies & 1 & 0,7 & 0,8 & 0,7 & 0,8 \\
\hline Air quality, and the emission of gases which cause the greenhouse effect & 1 & 1,1 & 1,1 & 1,16 & 1 \\
\hline Sewage treatment & 1 & 0,99 & 0,99 & 0,99 & 0,73 \\
\hline The new treatment plant and waste water treatment plants & 1 & 1 & 1 & 1 & 1 \\
\hline The area of green space, the extent of landscaping and assessment of green spaces of the city & 1 & 0,8 & 0,8 & 1,3 & 1,1 \\
\hline Assessment of Protected Areas & 1 & 0,9 & 0,9 & 0,7 & 0,9 \\
\hline Biodiversity and valuable natural areas & 1 & 0,93 & 0,9 & 0,87 & 0,81 \\
\hline
\end{tabular}

2. Air quality, and the emission of gases which cause the greenhouse effect. During last 10 years, the number of vehicles of individual car owners in Tatarstan is growing steadily. Consequently negative impact on the atmosphere of cities and towns is growing.

Emissions increases and the share of emissions from motor vehicles exceed $50 \%$ of total emissions, and continue to grow each year. The observed reduction in emissions from 2009 to 2010 explained by the transition to more environmentally friendly fuels.

During the Universiade staging vehicles and emissions near the venues have been calculated. The results of measurements of greenhouse gas emissions from motor vehicles, which were made after staging of the Universiade, 
showed that there are no exceedances of the maximum single MPC suspended solids, formaldehyde.

If we compare midlle concentrations of most greenhouse gases in 2013 to 2009, we can see, that it's increased by rising the concentration of sulfur dioxide. In the main, the content of sulfur oxides and particulate matter is increased. However, in general, their concentration remained at the same level due to lower concentrations of sulfur dioxide.

3. Sewage treatment. According to the municipal organization «Water canal», the number of subscribers served by the system-wide sanitation in connection with the Universiade 2013 increased. The volume of wastewater, which is cleaned by sewerage system, decreased, in compare to 2009. Maybe, the reduction of consumption of wastewater discharge occurred as a result of accounting for the expenditure of water and wastewater systems, the organization of work on the installation of water meters.

4. The new treatment plant and waste water treatment plants. According to the available materials, during the preparation for the Universiade there weren't built new plants to clean waste water and sewage. Number of installations during the Universiade and after it remained unchanged. So, activities in preparation for the Universiade and its staging are didn't not result in the construction of new facilities for cleaning waste water and sewage. At the same time we know, that construction of new wastewater treatment facilities to issue storm water, runoff flowing into the lake, was planned during the building of Rowing Centre on the Kaban lake. Saving numbers from the cleaning of waste and wastewater at the same level increases the load on the existing facilities. Also probability of accidents on existing installations is increasing.

5. The area of green space, the extent of landscaping and assessment of green spaces of the city. Active development and transformation of the urban environment in preparation for the Universiade are entailed a significant impact on all the main components of aquatic and terrestrial ecosystems. It has a negative impact on state of the air and water quality, reduced the greening of the city. Landscaping is the cheapest and most effective way to improve the ecological situation in the city. The number, location and quality of green space affects the quality and aesthetics of the urban environment, offer recreational opportunities, contribute to the conservation of biological diversity. The municipal authorities implemented the special programs " 100 squares" (2011) and "Green record" (2012-2014) with the purpose to alleviate the negative effects of the construction. In the course of them there was making of landscaping of green areas and the increase of degree of greening the city, creating a favorable environment for the future.

According to the inventory of green belt of Kazan 2007-2009, plantations to general use are allocated 697 green objects: the streets (508), parks (16), gardens (5), squares (109), green areas (58) and a forest park «Lebyazhie» in the status of protected areas (PAs), local values [4].

The share of green belt and percentage of landscaping decreased due to the construction of recent years, including the Universiade venues, there are suffered about 30 green zones. As a result of implementation of the «Green record», number of planted trees has increased by 100 thousand trees from 2012.

Preparation for the Universiade contributed to the rapid greening of the city and venues. Young spruce trees, lindens and rowns are dominated in in the species composition of tree species, which are used for landscaping. Shrub and flower forms distributed slightly.

According to the results of direct fieldwork 2013, which is held in the location of the Universiade and the greening surrounding areas, mostly the living condition of the trees estimated to 1 and 2 quality class - highly decorative healthy and slightly weakened trees. Unfortunately, due to the late planting (June-July), drying trees were observed, many trees were replanted later.

Flower beds and lawns are very important in the decoration of the city. They complement the activities and landscaping together with green spaces and they are an integral part of landscape decoration. According to the results of direct fieldwork 2013, which is held in the location of the Universiade, areas occupied by lawns amounted 26.24 hectares. Areas occupied by flower beds were small - about $1200 \mathrm{~m}^{2}$. The bulk of the flower beds and lawns in Kazan was established in 2013 before the Universiade. Mostly lawn quality estimated by 2-3 categories (satisfactory - unsatisfactory condition). Flower garden appropriated 1-2 category of quality (good - satisfactory condition).

So, we marked increase in the values of most of the indicators in 2013 (table 1).

6. Assessment of Protected Areas. At the present time, officially there are 6 regional PAs and 3 PA in the status of local natural monument in the city of Kazan [8]. During the Universiade 2013, neither of them fell under any direct impact, except Kazanka river in downstream in connection with the construction of venues in the floodplain.

This indicator shows assessment of changes in the state of protected areas in Kazan during the Universiade 2013 on the basis of the following criteria: 1) number; 2) the area of protected areas; 3) assessment of anthropogenic stress on natural systems of protected areas; 4) analysis of the species composition of PAs; 5) the presence of monitoring 
compliance with special protection.

Compare with the values of previous years, the number of existing protected areas in the city of Kazan and the area occupied by them during the Universiade unchanged. The calculation of the level of anthropogenic pressure on natural protected area complexes produced by using expert scores (1 point corresponds to a very low degree of human impact, 5 points - the highest). On the basis of adherence protection, size of the area of PAs, their location and factors of negative anthropogenic impacts in urban environments (recreation, debris, fishing), degree of anthropogenic stress for all PAs estimated in conditional values. Level of anthropogenic load in these conditions can be considered constant from year to year, because of lack of direct influence on the PAs during the Universiade.

The total number of protected areas has not changed under the influence of the Universiade. During the preparation of the XXVII World Summer Universiade 2013 we marked impact on the downstream of Kazanka river in connection with the construction of venues in the floodplain. Kazanka river is a monument of national importance in the upper and middle reaches. In this regard, the overall deteriorated. We marked disturbance of the natural habitat of plants and animals in the district of construction of the Universiade. Also valuable territories came under the impact, which earlier were planned as a protected area «lslands of Kazanka» (floodplain of Kazanka river).

The development of the environmental framework of the city is based on the protected areas, which are connected by a system of «green corridors». The existing ecological framework of the city was broken in the process of organizing and staging of the Universiade 2013, which requires the implementation of new methods of realization [9].

7. Biodiversity and valuable natural areas. The changing of biodiversity affected nearly all geographic clusters. The main trend is a general decline of species of plants and animals, including rare and endangered as a result of the destruction of natural habitats.

We revealed, that last period of time there was some reduction of biological diversity in all areas adjacent to the objects of the Universiade. The exception is the geographic cluster Kazan Volga region, where conservation and noted some increase biodiversity. This fact is due to the possibility of entering new data for the territories of plant species.

The value of natural areas, which estimated by the number of rare and endangered species [11], also has a negative trend. Everywhere is a tendency to reduce the number of rare species, up to complete disappearance.

The main reason for reducing the number of rare species is the transformation of natural habitat conditions as a result of the construction of the venues of Universiade. The restoration of these habitats are almost always not possible [12].

So, the preparation for the Universiade and its staging led to the destruction of natural habitats of plants and animals, including rare and endangered. As a result, a number of species fall out of the flora and fauna of the territory in question. During the period we marked the general trend of biodiversity loss and the reduction of the value of natural areas.

In general we marked deterioration of individual indicators and values of peer review on indicators (table 1). This kind of trend is due to a significant negative impact, exerted on the natural ecosystems of the city and valuable natural areas in the course of construction of the venues of the Universiade. In that period, there is irreversible destruction of historically established natural ecosystems, which affected most of the indicators.

The assessment of environmental damage is significant [1]. But the population of city is not aware of environmental degradation in the process of preparation and staging of the Universiade. We revealed by social analysis, that the main thing in staging of international competition like Universiade is a motivation to win, because of that people pay less attention on the questions of ecology [13].

\section{Conclusion}

The staging of large sports competitions is often have negative trends, which are associated with environmental degradation due to the construction of venues on valuable natural areas. Experience in organizing and staging of the Universiade 2013 in Kazan showed that almost all the main components of the environment were exposed.

The positive dynamic was marked due to changes in the area of green spaces and their condition. However, because of pre-existing indicators of landscaping Kazan (before 2004-2007), the state of green belt can also be considered deteriorate [5].

The population weakly recognize the trend of negative changes to the environment. It's will be possible only after tangible economic implications in the management of urban area, for example, the payment of economic damages and implementation of compensatory measures. 


\section{Credits}

The authors expressed their gratitude to Lipova A.V. for help with the translation of the text.

\section{References}

Derevenskaya O.Yu., Mingazova N.M., Mingaliev R.R., Pavlova L.R. Assessing Economic Losses of the Small River Ecosystems and Developing of Compensation Measures within the Framework of Sports Facilities Construction // Mediterranean Journal of Social Sciences. MCSER Publishing, Rome-Italy. 2014. - P. 345-348.

Malfas M., Theodoraki E., Houlihan B. (2004) Impacts of the Olympic Games as mega-events, Proceedings of the Institution of Civil Engineers: Municipal Engineer. - 2004. Issue ME3. - P. 209-220.

Mingazova N.M., Nikitin A.V., Yupina G.A., DerevenskayaO.Yu. Strategy of Management of City Development with Using «Green» Technologies (Kazan City, Russia) // Mediterranean Journal of Social Sciences. MCSER Publishing, Rome-Italy. 2014. - P. 341343.

Urazmetov, I.A., Smirnova, E.V., Kadyrova, R.G. Features of the soil of subboreal semihumid landscape zone within urbanized areas. Mediterranean Journal of Social Sciences, 5 (18 SPEC. ISSUE), pp. 373-377

Panasyuk M.V., Pudovik E.M., Sabirova M.E. Problems of labor market of modern Russia in conditions of stable economic growth. Life Science Journal 2014; 11(6s): 487 - 489.

National Register of Protected Areas in the Republic of Tatarstan. - Kazan: Idel-Press, 2007. - 408 p.

Nikitin A.V., Mingazova N.M., Yupina G.A. Problems of formation of ecological-natural framework of urbanized areas (for example, the city of Kazan) // Proceedings of the Kazan State Architectural University, 2010.№ 2 (14). - P. 88-96.

The concept of environmental protection in the preparation and conduct of the XXVII World Summer Universiade 2013 in Kazan with the action plan / FSI UralNII «Ecology», 2010. -123 p.

The Red Book of the Republic of Tatarstan (animals, plants, fungi). Second edition. - Kazan: Idel-Press, 2006. - 832 p.

Zamaletdinov R.I., Khairutdinov I.Z. Influence of the town development on conditions of living of amphibians and reptiles the fauna on the example of Kazan // Bulletin of the University of Tambov. Series: Natural and technical sciences. 2013. 18. T. Vol. 6. - P. 30063008.

Zamaletdinov R., Kornilov P., Mingazova N., Dautov A. Transformation of Social and Environmental Views during the Sporting Events (on an Example of the Kazan Universiade 2013) // Mediterranean Journal of Social Sciences. MCSER Publishing, Rome-Italy. 2014. - P. 235-239.

Urazmetov, I.A., Smirnova, E.V. (2014). Ecological state of water and soil of natural-anthropogenic landscapes in the oil-producing regions. Mediterranean Journal of Social Sciences, 5 (18 SPEC. ISSUE), pp. 367-372. 